\title{
Exploration of the Role of Dialogue Teaching in Enhancing the Affinity of Ideological and Political Theory Courses in Colleges and Universities*
}

\author{
Bilei Zhou \\ School of Marxism \\ South China Normal University \\ Guangzhou, China 510631
}

\begin{abstract}
The integration of dialogue teaching into the ideological and political theory course in colleges and universities is conducive to enhancing the subjective consciousness of students and truly making the content of the course "root deeply in mind." Constructing a dialogue teaching model of ideological and political theory should take the problem as a guide, sharing as a support, life as a material, and fusion as a purpose. In the classroom practice, it is necessary to focus on the content related to the course teaching, choose the "thinking point" of dialogue that can stimulate thinking, determine the "start" time fit for the content of the lecture, and grasp the "lift point" in the dialogue process and "enhance the affinity of the ideological and political theory class."
\end{abstract}

Keywords-ideological and political theory course teaching; dialogue; teaching method; affinity

\section{INTRODUCTION}

The term "affinity" is derived from chemical and biological terms, specifically referring to the relationship between one atom and another, and is widely extended to areas such as social psychology and education. The basis of the affinity of ideological and political education is the satisfaction of human needs and expectations, which contains the concept of people-oriented education. Therefore, we can define the affinity of ideological and political education as: the educator adheres to the people-oriented concept, and make the object of education have the sense of intimacy and acceptance to ideological and political education practice through the continuous optimization of educational activities, which is a kind of effect driving force for the promotion of ideological and political education. [1] The Propaganda Department of the Communist Party of China and the Ministry of Education clearly pointed out in the "Innovative Plan for the Construction of Ideological and Political Theory Courses in Colleges and Universities" that the ideological and political theory course is based on the

*Fund Project: Phased Achievements of Youth Innovation Project of South China Normal University; Phased Achievements of Youth

Innovation Talents Project of Colleges and Universities in Guangdong Province (Humanities and Social Sciences): Research on the Dialogue of Contemporary College Students' Ideological and Political Education (No 2017WQNCX025) support of Marxist theory. How to exert positive energy, enhance the explanatory power of major theory and real problems and establish dominance in pluralism is a new challenge faced by ideological and political theory courses. In recent years, ideological and political theory courses have achieved significant improvements in the preparation of teaching materials, the construction of teaching staff, and the improvement of teaching quality. Teaching is the central link of ideological and political theory courses. Only through effectively innovating teaching methods and mobilizing students to participate in enthusiasm can we enhance the affinity of ideological and political theory courses.

\section{INTRINSIC LOGIC OF THE IMPROVEMENT OF AFFINITY OF IDEOLOGICAL AND POLITICAL THEORY COURSE AND DIALOGUE EDUCATION}

The dialogue teaching of the ideological and political theory courses gives us a new way of thinking about how to seek consensus in multiple discourses. In the face of complicated new situations and new problems, we will explore the use of dialogue teaching in the classroom teaching of ideological and political theory courses, so that the content of the course will "root deeply in mind".

\section{A. The Concept of Dialogue Teaching Is Consistent with the Improvement of the Affinity of Ideological and Political Theory Course}

There is consistency between the teaching philosophy of dialogue teaching and the goal of the ideological and political theory course. The fundamental purpose of establishing an ideological and political education curriculum is to achieve the all-round development of students and the focus is educating people. The success of the ideological and political education course depends on whether it can teach students to establish a correct world outlook, outlook on life and values, and impart students a scientific way of thinking, spiritual beliefs and survival wisdom to strengthen their own beliefs without being changed easily when facing all kinds of complicated problems. Today, when various trends of thought make their own voice in the Internet, how can we play a leading role in pluralism and get consensus in various voices? The dialogue 
teaching of the ideological and political theory class gives us the enlightenment to resolve this dilemma. First of all, from the perspective of value judgment, the dialogue relationship reflects the mutual exchange of thoughts, emotions, and information of different words, including the values of right and wrong, true and false, good and evil, and beauty and ugliness, and thus has value attributes. Secondly, from the perspective of the activities of human consciousness and thinking, there is no independent thought without foundation and followers. Any thought has a certain historical inheritance. This is because people's thoughts come from the understanding of things, but each person's vision is inevitably limited, which requires the consciousness of others (including predecessors) to interact with them. The process of "dialogue" is the process of value selection for this consciousness, thus constantly pushing people's thoughts closer to truth and consensus. Thirdly, the dialogue between people has become the relationship between the individual and the society. It not only reflects the social existence of the human being, but also reflects the open thinking mode of multi-symbiosis. [2] The value attribute contained in the dialogue teaching has the same effect as the value education that the ideological and political theory course needs to convey. It is also an inherent requirement of the teaching of ideological and political theory class to form correct value choices and consensus and identity in pluralistic thoughts through dialogue teaching.

\section{B. The Effectiveness of Dialogue Teaching Matches the Improvement of the Affinity of Ideological and Political Theory Courses}

Dialogue teaching has been widely used in subject teaching, and integrating the dialogue teaching into the ideological and political classroom has its own unique effects in enhancing the students' participation in the classroom and improving the teaching effect. First of all, students have already learned some relevant ideological and political lessons in middle school, and they have certain cognitive foundations, so ideological and political classes tend to be ignored by students. The dialogue teaching method of ideological and political courses helps students to participate in classroom teaching, to activate the classroom atmosphere and stimulate students' interest in learning. Secondly, it is conducive to connecting with the reality. Topics are set focusing on the social hotspots and the actual situation of the students, which not only allows students to pay attention to the real society, but also helps students apply what they have learned to everyday life and think. We should pay close attention to online life, emotional problems and personal development issues and not only stay at the level of theoretical analysis, but also touch the "fundamental" of these problems to enter the hearts of students and arouse students' resonance. Third, it helps to enhance the understanding of teaching content (knowledge). With empty preaching and the monologue of "one person saying", even the authoritative preaching cannot make students have interest and internalize the knowledge. Not only do students have to "understand", but also "remember" and "implement". Teaching is the transmission of knowledge - the teaching of politics should "root deeply in mind", touch the students, so that the abstract theory can be absorbed and transformed into action by the learners, and dialogue teaching can play a certain role.

\section{The Method of Dialogue Teaching Promotes the Improvement of the Affinity of Ideological and Political Theory Courses}

The contents and tasks of the ideological and political theory course determine that its teaching method should be different from that of natural science. It should not only complete the knowledge transfer of "what is it", but also has the important role of enlightening wisdom and thought leadership. Dialogue teaching is in line with the reality of Chinese education and meets the requirements of the ideological and political education classroom. The method of dialogue teaching is consistent with the task requirements of the ideological and political theory course. The "bag of virtues" advocated by western moral education is not a dialogue interaction, and the purpose is to let students remember; while the "value clarification method" has interaction, allows students to make self-selection in thinking, and the individual can acquire knowledge construction in interaction with teachers, but it is not suitable for large classroom teaching in Chinese universities. The origin of dialogue teaching runs through ancient and modern times. Socrates' "Socratic Method", the dialogue between Confucius and his disciples, and the Buddhist Zen path are the "embryonic form" of dialogue teaching. In the "Education of the Oppressed", Freire proposed that dialogue is the living state of people. David Bohm's principle of dialogue emphasizes collision of thoughts and elimination of foresight. Sato's theory puts forward the teaching mode of "human dialogue" and "students' dialogue" and "dialogue between teachers and students". All these provide a theoretical foundation for dialogue teaching. Dialogue teaching is suitable for classroom teaching in political classes in China. Teachers use dialogue to develop dialogue between teachers and students, organize student class discussions, and dialogue with texts, which is convenient and effective. It can enhance the affinity and appeal of ideological and political theory courses when stimulating students' interest.

\section{THE PATH CONSTRUCTION OF INTEGRATING DIALOGUE TEACHING INTO THE IDEOLOGICAL AND POLITICAL THEORY CLASS}

To construct a dialogue teaching model of ideological and political theory courses, we should adhere to the problem-oriented approach and take sharing as the support, life as the material, and fusion as the purpose.

\section{A. Taking the Problem as a Guide to Arouse Resonance}

In the teaching of ideological and political theory class, we should consider the logic of topic setting, not only from the perspective of activating classrooms and the interaction between teachers and students, but more importantly, it should think about the doubts of students' concerns, throw problems, arouse resonance and promote think, so that students review their own way of thinking, and form a consensus in the dialogue. Marx once said: "As long as the 
theory persuades people, it can grasp the masses; and if the theory is thorough, it can convince people. The so-called thoroughness is to grasp the root of things, but the root of human is the human." The focus of the dialogue is the core of dialogue teaching in the ideological and political theory class. In the classroom, it is suggested to center on the requirements of the syllabus, combine with different situations, focus on the needs of teaching objects, and use thematic inquiry, question and answer, conversation and other methods to form teaching actions.

\section{B. Taking Sharing as Support and Respecting Differences}

In the interaction with others (especially many people), people will absorb the diversity and difference of others' development into their own development, such as absorbing other people's ideas, ways of thinking, behaviors, etc., so that their inner world become rich, open, flexible and diverse." In the ideological and political education of college students, there are specialties and differences between educators and educators and different educated people. It is necessary to pay full attention to the exchanges and dialogues between the main subjects of education, understand mutually, reach consensus and constantly improve oneself and develop oneself. Through two-way interaction, it demonstrates the important role of dialogue teaching in the ideological and political classroom, and make it truly enters the students' minds and hearts. Different students are made to communicate with each other, the two-way communication between teachers and students is promoted, and more sparks of wisdom burst out.

\section{Taking Life as the Material and Being Close to Students}

Ideological and political education must not only be based on the scientific discipline guidance, but also the realization of the life world. Education has significance only in life, so only by returning to life can education realize its sincerity. Dialogue teaching can go beyond the domain of "people", get close to the reality of students, and pay attention to the life world of students. Words come from life, and life is the place of cases for education. Gadamer believes that the world of life is "the most intrinsic understanding and deep sharing. The ideas, values, and customs shared by all of us are the sum of all the conceptual details that make up our living system." [3] By sharing the stories around the students, we can get close to the hotspots concerned by students, improve the discourse appeal of dialogue teaching, and give them inner life meaning in the process of knowledge construction. For example, through the display of the hometown on the tip of the tongue, students can share and introduce their hometown in the form of ppt, video, micromovie, etc., and then the special subject education of "love the motherland and love the nation" can be carried out on the basis of sensibility.

\section{Promoting Construction with the Purpose of Integration}

Marx pointed out that "the generation of ideas, ideas, and consciousness is directly intertwined with the material activities of people, the material interactions of people, and the language of real life. People's imagination, thinking, and spiritual interaction are the direct products of people's material actions." [4] It can be seen that college students gradually form ideological and political morality in the practice of communication, and this kind of practice has the nature of dialogue and communication. Once teaching is based on communication of dialogue, teaching goes far beyond the role of information transmission, because the educated people constantly construct their own knowledge system in the interactive "conversational communication" and generate meaning and value, which goes far beyond the simple knowledge transfer. In the dialogue with others, they can express their own thoughts when absorbing other people's information, thus constructing new cognitions and insights, and promoting the creation of new meanings. The process of ideological and political education forms a learning community that participates in educational activities based on the basis of this dialogue and communication, and achieves common understanding through interactive communication and mutual understanding.

\section{The SPECIFIC IMPlementation OF Dialogue TEACHING IN IDEOLOGICAL AND POLITICAL THEORY COURSES}

In the process of practice, the dialogue teaching of ideological and political theory courses closely follows the content of "teaching points" related to the curriculum teaching, selects the "thinking point" that can stimulate thinking, and determines the "cut-in point" for the time to adapt to the lecture content, focus on the content related to the course teaching and grasp the "lift point" in the dialogue process.

\section{A. Focusing on the "Teaching Points" of Content Related to the Course Teaching}

First of all, it is suggested to closely focus on the teaching content to highlight key points and difficulties, and set the content and problems of the dialogue in a targeted manner to truly make the dialogue teaching serve the teaching objectives and central tasks of the ideological and political theory course, and avoid dialogue becoming "performance" or random "chat". As a public course, the ideological and political course is different from the professional course and is featured large class teaching, limited time, and wide knowledge coverage. As teachers, it is impossible to carry out dialogue teaching for each knowledge point, so they can focus on the content of the ideological level involving values according to the key points and difficulties of teaching. For example, they can rely on the answers to 30 key and difficult questions organized by the Department of Ideological and political work of the Ministry of Education, such as how to understand patriotism in the context of economic globalization, how to fully understand the connotation and significance of "freedom" in the core values of socialism, etc., so that they can continuously build consensus and realize mutual benefits during the discussion. In the process of dialogue teaching, it is necessary for teacher to grasp the difficulty level of the problem, which should not only reflect the theoretical nature of the subject, but also grasp the cognition degree of students, 
so that students have words to say and are willing to share. They can focus on the discussion related to the core value, and let students think and analyze in the dialogue teaching through the careful setting of the topic to arouse extensive communication, create collision of thinking, promote students' knowledge construction, and enhance the internalization of values. Secondly, it is suggested to pay attention to social hotspots and set open dialogue topics. It is necessary to have a broad vision, a sense of social responsibility and a caring mind to feel the social hotspots. As an important way to spread the core values, the ideological and political theory class should closely integrate the course content with the students' daily life, be close to the actual growth of college students, update the teaching cases in a timely manner, keep up with the development of the times and international changes, root in the soil of life, draw materials from life and learn to think and discern in life. By taking materials of daily life of college students, we select social hotspots with high attention, carefully select and deepen refinement as vivid teaching materials. For example, it is possible to discuss "the reflection behind the toxic vaccine event" from an ethical and legal level.

\section{B. Choosing the "Thinking Point" of Dialogue That Can Stimulate Thinking}

First, the depth of the problem is highlighted by the logical reasoning of "painstaking investigation". The process of dialogue teaching needs to be rational and arguing. Students participate in dialogue through known knowledge and experience, gain knowledge in dialogue teaching, as well as improve thinking and subjective consciousness. Through the novel and innovative classroom theme discussion, teachers can truly explain the major principles and illustrate the minor principles, and enhance the vitality of the classroom, so that the ideological and political lesson have a sense of existence among the students, and students have the sense of gain after the collision of knowledge and thoughts. After class, we pay attention to students' Weibo, WeChat, and QQ, to timely and comprehensively understand and master the students' ideological dynamics, respond to the hotspots that students have vague cognition or controversial opinions, and discuss deep-seated issues through discussion or debate, so that the ideological and political class can truly "root deeply in mind" Second, thinking with extrapolation can highlight the breadth of the problem. We should not only stay at the surface of the problem, but also have the collision and integration of different disciplines and different horizons. In the topic of value, it is possible to introduce the MBTI test of career development and the exploration of career anchor, so that students can clearly know their direction in the dialogue with themselves. With empty preaching and the monologue of "one person saying", even the authoritative preaching cannot make students have interest and internalize the knowledge. The educational process should pay attention to the process from cognition to emotion to behavior. Therefore, establishing a firm ideal and belief must be fully demonstrated on the basis of the facts of advancing with the times, in order to truly construct students' cognition and identity. The classroom teaching mode of ideological and political education should abandon the monologue mode, change the preaching to reasoning, and change the "monologue comic talk" into "collective symphony", to make the educational concept and value "deep in the mind" rather than the form of copying. For example, it is suggested to interpret the relationship between law, personal interests and collective interests combining with the case of "college students stealing state secrets".

\section{Determining the "Entry Point" of Time to Adapt to the Content of the Course}

Teachers should carefully grasp the "time point" of setting topics. First, the "leading" heuristic question is suitable for the beginning of the chapter as the "introduction", the leading topic throughout the chapter should be carefully designed, and the series questions are brought by the topic. There are grads between questions, from shallow to deep and "onions-peeling" questioning links problems to the core, building a bridge between problems and nature. The problems are interlocking, and the logical advancement is deeper, which stimulates the students' thinking ability, so that students not only know "what it is", but also understand the "why it is". Secondly, the "time of entry" of the "answering" problem should be arranged based on the difficulty of the chapter to promptly respond and answer students' confusion about knowledge. It should root in the textbook and the fixed course text and design cleverly to enhance students' understanding to textbook and mastery of knowledge. Especially when students have deviations in understanding knowledge, teachers need to introduce dialogues to find their misunderstandings and promptly dial them, and prompt guide them, give hint and correct them. For example, they can discuss the ethical experiment tram problem and analyze the prisoner's dilemma, etc., to form a certain consensus on moral choice through the sharing and collision of academics. Thus they can achieve understanding in each other's trust and realize mutual benefit in understanding. Third, the vital comprehensive problems are suitable for the end of the chapter, to play the role of summary and improvement. According to the student's knowledge structure and ability level, combined with the students' daily attention hotspots, it is necessary to pay attention to the "openness" of the problem, avoid "invalid question and answer", "false question and answer" and "empty question", and constantly add one's own thinking and discourse in the discussion of the topic to reach understanding and consensus in the interaction, and constantly improve students' attention and thinking on social hotspots. For example, the People's University of China has opened the "WeChat Public Account for ethics and selfcultivation course" - "Don't laugh at me as ethics and selfcultivation course". In the various thematic activities of "patriotism moments", "things about ethics" and "this is happiness", the characteristics of the Internet age are used and combined with patriotism, life value, and morality in the curriculum.

\section{Grasping the "Upgrade Points" in the Process of Dialogue Teaching}

The classroom teaching time of ideological and political subjects is short, so it is impossible to have unlimited 
dialogue for a long time; the development and mastery of dialogue must be carefully designed and effectively used by teachers. All the dialogues start from the setting of the topic. The elaborate setting of the topic is the core of the successful dialogue teaching of the ideological and political theory class. First of all, the issues involved in dialogue teaching should be novel and inspiring. For example, in the chapter on ideals and beliefs, some students think that "a promising future $=\mathrm{a}$ rich future." We can start a conversation by discussing "what is success and what is the future." Dialogue teaching can not only activate the classroom atmosphere and enhance students' participation and attention, but also improve students' ability to think and discriminate, deepen students' mastery of knowledge, and internalize into their own values. The dialogue teaching of ideological and political theory should be based on reality and lead the students' thinking. It is necessary not only to let the students be placed in the broad background of the times and draw materials from life, and but also to reflect the systematic system of theory and the rationality of the curriculum. Dialogue setting should be novel and innovative. After the topic is thrown, it can immediately trigger students' interest, face the students' doubts and confusions, and strive to promote consensus in dialectical criticism. Secondly, the issues involved should be moderately difficult. On the one hand, it is necessary to set up dialogues closely related to the requirements of the curriculum. On the other hand, it is necessary to take into account the professional background and knowledge structure of the students. It is suggested to deal with the relationship between the syllabus and the topic setting, not only to prevent the problem from being too academic to resonate with the students, but also to prevent the students from leaving the course requirements. Third, the problem should be open, both to touch the "switch" for students to share, and not to let the classroom fall into the "general speaking".

\section{Points That NeEd ATtention in Dialogue \\ TEACHING IN IDEOLOGICAL AND POLITICAL COURSES}

The dialogue teaching method of ideological and political theory is our exploration in classroom practice. It is necessary to further enhance the theory to form a practical path with its own curriculum characteristics. In this process, we should pay attention to the following issues.

\section{A. The Relationship Between Dialogue and Indoctrination}

The core of education is not to teach what is already there, but to evoke people's creative power and to reflect people's sense of life and value. It is necessary to instill the theory, but we often simply take instilling theory as the teaching method of duck-stuffing indoctrination. Instilling principle is a must, but only relying on the method of indoctrination cannot realize knowledge transfer and thought lead, and can't complete the process of individual cognition from "don't know" to "know", from "know" to "firmly believe", and then to "practice". As a method of classroom teaching, dialogue teaching of ideological and political theory courses is combined with expository method and reading methods to complement each other. For example, when facing the chapters with strong theoretical property and logicality, teachers can mainly adopt expository method while for the chapters that are inspiring and closely related to life, the methods can be mainly based on dialogue teaching. They can break the closed and static mode of the previous classroom, and form a learning community in the classroom by organizing students' participatory learning, experiential learning and collaborative learning. In the open interaction and the inquiry-based sharing, relying on dialogue teaching, the learning subjects can be integrated in different perspectives, generate new construction, realize selfdevelopment, and feel the value and significance of the curriculum. Through dialogue teaching, they can help students carry out the art of discussion and dialogue according to certain rules, learn to listen and understand others' views, learn to treat criticisms kindly to examine their own views, and learn to accept, appreciate and help each other, thus promoting students' collaborative learning ability, organizational skills and communication skills, and striving to form a dialogic, cooperative, and efficient learning community to jointly cultivate students' team spirit and collective ideas.

\section{B. Relationship Between Teachers and Students}

Teachers are leaders who guide the smooth progress of the dialogue, so they should have good design, good questions, and ideas; teachers can't fall into the routine of performance and pure technology. Dialogue teaching adheres to the establishment of a good teacher-student interaction, and teachers appear with equal authority. This equality is reflected in the equality of personality and legal meaning, and this authority is willing to share and listen, which is separated from the system authority. Therefore, the teachers can narrow the distance from the students, know what the students think, enhances the participation of the class by directly facing the students' attention points, breaks the students' stereotypes about the high teachers, and truly enters the students' "friends circle". Enhancing the recognition of teachers of the ideological and political theory class help students receive education in a relaxed and lively classroom atmosphere, accept and like the class and form resonance. Dialogue teaching advocates the establishment of the relationship between "I and you", so as to achieve the spiritual encounter and sincere understanding between teachers and students, and finally reach a consensus and achieve symbiosis.

\section{CONCLUSION}

All classroom teaching is inseparable from communication and quality and meaningful teaching activities have the nature of dialogue. The dialogue runs through the whole process of education and reflects all the relationships contained in education. Education itself contains the spirit of dialogue. Introducing the method of dialogue teaching in ideological and political theory course can let the ideological and political theory class "root deeply in mind" of college students, and truly enhance the attraction, appeal, and influence of ideological and political theory courses. 


\section{REFERENCES}

[1] Li Jian. Research on the Elements and Formation Mechanism of Affinity of Ideological and Political Education [J]. Studies in Ideological Education, 2017(3): 37. (in Chinese)

[2] Xiao Jingyu. Transcendent Linguistics [M]. Shanghai: Shanghai People's Publishing House, 2007: 116-117. (in Chinese)

[3] [German] Gadamer. Praise Theory [M]. Tr. Xia Zhenping. Beijing: SDX Joint Publishing Company, 1988:69. (in Chinese)

[4] Marx, Engels. Collection of Marx and Engels (Volume I) [M]. Beijing: People's Publishing House, 1995: 72. (in Chinese) 